\title{
İlişkisel Pazarlamanın İlişki Kalitesi Üzerindeki Etkileri: Kars İli Cep Telefonu Kullanıcıları Üzerinde Bir Araştırma ${ }^{1}$
}

\author{
Çağlar Samsa a*, Levent Gelibolu ${ }^{\mathrm{b}}$ \\ a, Kafkas Üniversitesi, İktisadi ve İdari Bilimler Fakültesi, Kars.
}

\begin{abstract}
$\ddot{O} z$
Ürün farklılaştırmanın çok zorlaştı̆̆g güncel pazarlama koşullarında farklılık yaratabilmek için ilişkisel pazarlama aktif olarak kullanılmaktadır. Özellikle son 10 yılda büyük gelişme gösteren GSM sektörü de ilişkisel pazarlama yöntemlerinin en fazla kullanıldığı bir alandır. Kars ili GSM operatörü müşterileri üzerine yapılan bu çalışmada tesadüfì örneklem kullanılmış, veriler anket yöntemi ile elde edilmiştir. Anket verilerinin yorumlanması aşamasında ise SPSS ve LISREL programlarından faydalanılmıştır. Çalışmada, ilişkisel pazarlama yöntemlerinden hizmet kalitesi ve şirket imajınn müşteri memnuniyeti ve müşteri güvenini olumlu yönde etkilediği belirlenmiştir. Bununla birlikte fiyat algısının müşteri memnuniyeti ve güvenini etkilemediğ $i$, marka imajının ise müşteri memnuniyeti ve güveni üzerinde negatif yönde etkiye sahip olduğu görülmüştür. İlişki kalitesi faktörlerinden memnuniyetin ise müşteri sadakatini en çok etkileyen faktör olduğu sonucuna ulaşılmıştır.
\end{abstract}

Anahtar kelimeler: İlişkisel Pazarlama, Hizmet Pazarlaması, Müşteri Sadakati, Müşteri Memnuniyeti, Müşteri Güveni

\section{The Effects of Relationship Marketing on Relationship Quality: A Study on the Mobile Telephone Users in City of Kars}

\begin{abstract}
The relationship marketing has been used actively to create diversification in current marketing conditions in which the diversification has been becoming very difficult. Especially the GSM sector performing a rapid development in the last ten years is an area in which the relationship marketing methods have mostly been used. In this study conducted on the customers of GSM operators random sampling method was used, the data were collected using a questionnaire. The data were analyzed by using SPSS and LISREL programmes.It was found out that the service quality and the company image of relationship marketing methods effect the customer satisfaction and confidence positively. However it was understood that the price perception do not effect the customer satisfaction and confidence, and also the brand image had a negative effect on the customer satisfaction and confidence. As a result of this study it was clearly understood that the satisfaction, one of the relationship factors was the most important factor effecting the customer loyalty.
\end{abstract}

Keywords: Relationship Marketing, Service Marketing, Customer Loyalty, Customer Satisfaction, Customer Confidence.

\footnotetext{
${ }^{1}$ Bu çalışma Kafkas Üniversitesi Sosyal Bilimler Enstitüsüne sunulan “ İlişkisel Pazarlama Yöntemlerinin İlişki Kalitesi Üzerindeki Etkileri: Kars GSM Sektörü Örneği” isimli yüksek lisans tezinden uyarlanmıştır.
} 


\section{GİRIŞ}

Rekabetin giderek arttığ1, müşteri elde etmenin ve tutmanın giderek zorlaştığ günümüz pazar koşullarında, müşteriye sunulan ürün ve hizmeti farklılaştırmak oldukça güçleşmiştir. Dolayısıyla müşteri memnuniyeti açısından en önemli faktörlerden birisi de müşterilerle iyi ilişkiler kurabilmektir. Birçok sektörde olduğu gibi GSM sektöründe de işletmeler müşteri elde etmek için ilişkisel pazarlama yöntemlerine başvurma gereği duymaktadır.

Özellikle son yıllarda yaşanan teknolojik değişim ve bu değişimle birlikte oluşan teknolojik gereksinimler GSM sektörünü büyük sektörlerden biri haline getirmiştir. Dolayısıyla müşteri sayısı ile hizmet sunanların artışı aynı düzeyde olmamış, firmaların müşteri kazanma ve tutma çabalarında rekabet daha da artmıştır. Yaşanan bu gelişmeler 1şı̆̆ında işletmeler için en önemli çabalardan birisi de ilişkisel pazarlama yöntemlerini etkin bir şekilde kullanarak sadık müşteriler edinmek ve bu sayede işletme devamlılığını sağlamaktır.

Çalışmanın ilk bölümünde ilişkisel pazarlama ve yöntemleri konusuna yer verilmiş, uygulama kısmında ise GSM sektörüne kısaca değinilmiş ilişkisel pazarlama yöntemlerinin Kars ilinde yaşayan cep telefonu kullanıcıları üzerindeki ilişki kalitesi incelenmiştir.

\section{1. İLISSKISSEL PAZARLAMA}

İlişkisel pazarlama, müşterilerle uzun dönemli yakın ilişkiler kurarak rekabet gücü ve müşterini tatminini artırmak için uzun dönemde işletmelerin ilişki maliyetlerini azaltmak amacıyla uyguladıkları stratejiler olarak ifade edilebilir (Ekici ve Yüce, 2007: 52). Bu bağlamda ilişkisel pazarlama anlayışının temel amacı, müşteri ile ilişki başlatma, geliştirme ve bu ilişkiyi devam ettirmektir. Kurulan bu ilişki işletmelere rekabet avantajı sağlar ve müşteri odaklı anlayış benimsenerek sadık müşteriler elde edilebilir (Chiu vd, 2005: 1683).

Hizmet sektöründe rekabet üstünlüğü ve işletme başarısı sağlamak için uygulanan en önemli ilişkisel pazarlama yöntemlerinin başında; hizmet kalitesi, fiyat algısı, marka imajı ve şirket imajı gelmektedir.

Hizmet Kalitesi; Hizmet kavramı, "Başka biri için iş icra etmek" şeklinde tanımlanabilir (Goests ve Davids akt. Rahman vd, 2007: 39). Hizmet kalitesi kavramını ise verilen hizmetin müşteri beklentileriyle örtüşme düzeyi olarak tanımlamak mümkündür (Bozdağ akt. Filiz vd, 2010: 62 ). İşletmeler için rekabet avantaj1 sağlamanın en iyi yolu hizmet kalitesinde farklılık yaratabilmektir. Kaliteli hizmet müşteri memnuniyetini de arttıracaktır. Kaliteli hizmet, müşteri kaybını azaltmak ve müşteri şikayetlerini çözmek için harcanan zaman ve paradan tasarruf etmek, yeni müşteriler kazanmak ve mevcut müşterileri elde tutmak için yapılan reklam masraflarını azaltmak ve ağızdan ağza iletişim yoluyla masrafsız reklam yapılması gibi avantajlar sağlamaktadır (Hacıefendi ve Koç, 2009: 148-149). 
Fiyat Algısı; TDK tanımına göre fiyat, "Alım veya satımda bir şeyin para karşılığındaki değgeri, eder, paha" olarak tanımlanmıştır. Algı ise, "Bir şeye dikkati yönelterek o şeyin bilincine varma" olarak tanımlanabilmektedir (tdk.gov.tr). Bu tanımlar göz önünde tutularak fiyat alg1sı; herhangi bir ürün veya hizmetin alım veya satımdaki para karşılığındaki değerinin müşteri zihnindeki yeri olarak ifade edilebilir.

Marka İmajı; bir kişi veya kişiler grubunun bir ürünle ilgili duygusal ve rasyonel değerlendirmelerinin tümünü (Peltekoğlu, 2007: 584) ifade etmekle birlikte inanç ve çağrışımları da (Yalçınkaya, 2006: 7) kapsamaktadır. Tüketiciler ürün veya marka tercihlerini zihinlerinde oluşan imaja göre şekillendirmektedirler. Markanın oluşma süreci bünyesinde pek çok faktörü barındırsa da günümüz rekabet piyasasında fark yaratabilecek en büyük unsur müşteri ile iletişime geçmek ve bu sayede olumlu marka imaji yaratmaktır (Yurdakul, 2003: 209).

Şirket İmajı; şirket imajıyla ilgili geçmişten günümüze en genel ve açıklayıcı tanım "Insanların şirket hakkında sahip oldukları algıların resmi" olarak ifade edilebilir (Kökalan, 2004: 9). Gelişen pazar koşulları ürün imajına ek olarak şirket imajının da organizasyonların ürün ve hizmet satışını arttıran önemli etmenlerden biri olmasına neden olmuştur. Şirket imajı organizasyonların en ayırt edici özelliklerinden biri olarak karşımıza çıkmaktadır. Güçlü şirket imajına sahip kuruluşların iç ve dış müşterileri organizasyon içine çekebilecekleri öngörülmektedir (Erdoğan vd. , 2006: 56).

İlişkisel pazarlamada ilişki kalitesinin belirleyici unsurları; müşteri memnuniyeti, müşteri güveni ve müşteri sadakatidir.

Müşteri Memnuniyeti; müşterilerin ürün veya hizmetten elde ettikleri sonucun beklentileri karşılama düzeyidir (Burcuoğlu, 2011: 14). Müşteri memnuniyeti açısından işletmelerin kullandığı en önemli kaynak müşteri şikayet ve öneri sistemleridir. Müşterilerin çoğu şikayet ve önerilerini işletmeyle paylaşmak yerine yakın çevresiyle paylaşmakta (Pappers: 39), müşterilerin sadece \%4 ü şikayetlerini dile getirmekte, memnun kalmayan müşteri memnuniyetsizliğini 10 kişiye anlattığ1 Gerson (1997: 2122) görülmektedir. $\mathrm{Bu}$ açıdan değerlendirildiğinde memnun olmayan müşterilerin, işletme açısından büyük kayıplara neden olduğu görülmektedir.

Müşteri Güveni; taraflardan birinin, diğer tarafın vermiş olduğu vaatleri yerine getirip getirmeyeceğine yönelik inancı olarak tanımlanabilmektedir. İlişkisel pazarlamada amaç müşteri güvenini elde ettikten sonra müşteri sadakati oluşturarak uzun dönemli müşteriler elde etmektir (Haciefendioğlu ve Çolular, 2008: 110).

Müsşteri Sadakati; müşterilerin tercih ettiği ürün, hizmet veya markayı tekrar satın almaya devam etmesi (Bowen ve Chen, 2001: 213), belli ürünleri ve hizmetleri satın alma davranışını tekrarlaması (Fornell,1992 akt. Raza ve Rehman, 2012: 5087), ve satın alma sonrasında ürün veya hizmete karşı hislerinin ve tutumlarının değişmemesi olarak ifade edilebilmektedir (Hashem, 2012: 144). Müşteri sadakati, mevcut müşterilerin korunması amacıyla müşteri değeri yaratma ve bu değerin müşteriye sunulması, yeni müşteriler ile ilişkiler sonucunda işletmeye bağlılığının arttırılmasını sağlamaktadır (Bayuk ve Küçük,2007: 287). Mal ve hizmet üreten ve satan işletmeler 
müşteri memnuniyetini sağladıkları sürece hedeflerine ulaşabilirler ve sadık müşteriler elde edebilirler (Özdağoğlu vd. 2008: 368).

\section{ARAŞTIRMANIN KAPSAMI, MODELİ VE HIPOTEZLERI}

Günümüz piyasasında ilişkisel pazarlama, tüm sektörlerde kendine yer bulmaktadır. Bu sektörlerden biri de teknolojinin gelişmesine paralel olarak günden güne gelişen GSM sektörüdür. 2014 yılı verilerine göre Türkiye'de 70 milyonu aşkın GSM Operatörü kullanıcısı bulunmaktadır (teknolojigundem.com). Yine TUIKK (Türkiye İstatistik Kurumu) 2014 verilerine göre Türkiye'nin nüfusu ortalama 77 milyondur (tuik.gov.tr). Yani Türkiye nüfusunun yaklaşık \%91'i GSM operatörü kullanmaktadır. Bu veriler dikkate alınarak yapılan araştırmada, uygulama alanı olarak Kars ilinde GSM Operatörü kullanan tüketiciler seçilmiştir. GSM sektöründe ilişkisel pazarlama yöntemlerinin ilişki kalitesi üzerindeki etkisi ölçülmüş; ilişki kalitesinin ise müşteri sadakati üzerindeki etkileri araştırılmıştır.

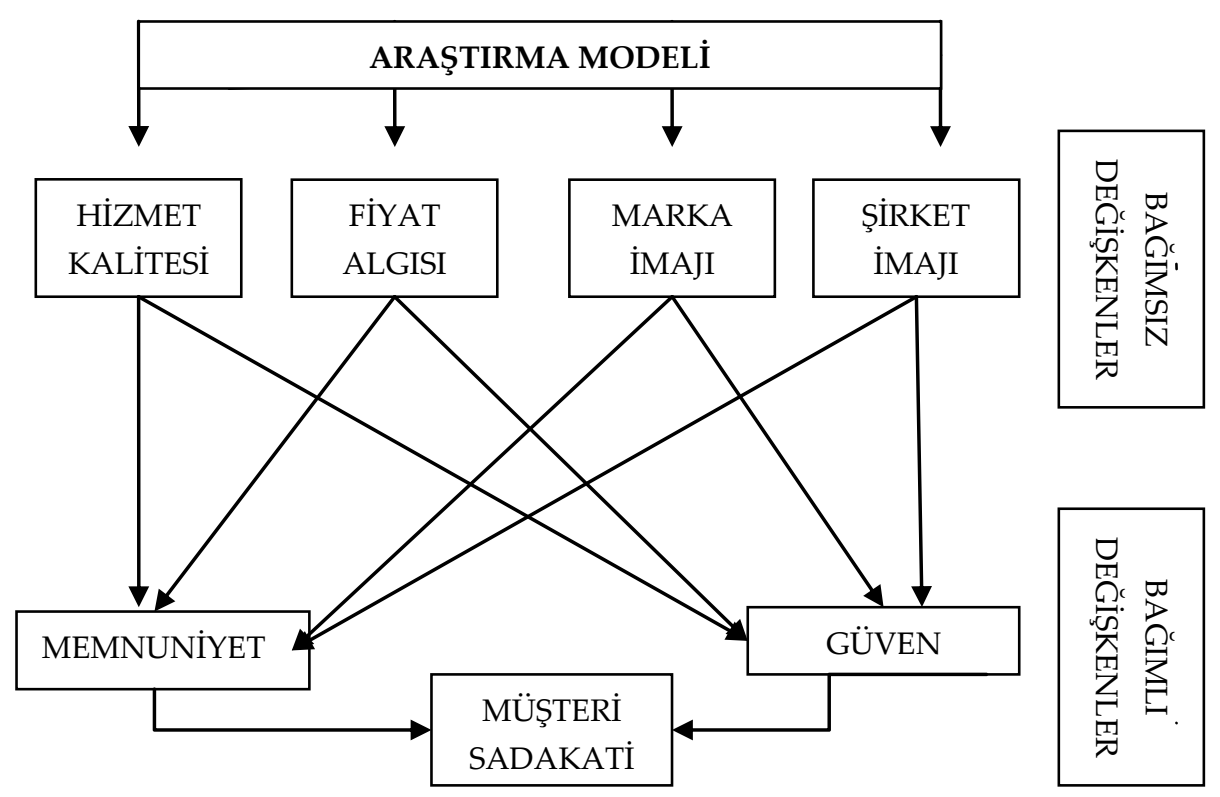

Şekil 1: Araştırma Modeli

\subsection{Araştırma Hipotezleri}

Çalışmadaki hipotezler aşağıda sıralanmıştır.

H1: Hizmet kalitesi müşteri memnuniyetini etkiler.

H2: Hizmet kalitesi müşteri güvenini etkiler

H3: Fiyat düzeyi müşteri memnuniyetini etkiler.

H4: Fiyat düzeyi müşteri güvenini etkiler.

H5: Marka imajı müşteri memnuniyetini etkiler.

H6: Marka imajı müşteri güvenini etkiler. 
H7: Şirket İmajı müşteri memnuniyetini etkiler.

H8: Şirket imajı müşteri güvenini etkiler.

H9: Müşteri güveni müşteri sadakatini etkiler.

H10: Müşteri memnuniyeti müşteri sadakatini etkiler.

\subsection{Araştırmanın Amacı ve Yöntemi}

Müşteri odaklı anlayışın önemli olduğu günümüz pazar koşullarında başarı için en önemli faktörlerden biri olan müşteri, işletme başarısı ve devamlılığında aktif rol oynamaktadır. Teknolojinin gelişmesi, ürünlerin daha kolay taklit edilebilmesi ve ürün çeşitliliğinin artması müşteriyi işletmelerin sahip olduğu en değerli varlık haline getirmiştir. Daha fazla seçeneğe sahip olan tüketiciler daha bilinçli hale gelmiş, bilinçlenen tüketici ise firmaları rekabete zorlamıştır. Müşteri odaklı anlayışın hakim olduğu günümüz koşullarında, işletmelerin faydalandığı kaynakların başında ilişkisel pazarlama gelmektedir. Bu duruma paralel olarak yapılan çalışmada da müşteri odaklı anlayışın etkileri incelenmiş ve sadık müşteri oluşturma yolunda ilişkisel pazarlama yöntemlerinin etkisi araştırılmıştır. Ayrıca araştırmada, müşteri sadakati için hangi ilişkisel pazarlama yönteminin daha pozitif katkıda bulunduğu ve farklı ilişkisel pazarlama yöntemlerinin müşteri sadakatini nasıl etkilediği gibi sorulara cevaplar aranmiştır.

Çalışmada günümüz koşullarında müşteri odaklı anlayışın temeli olarak ifade edilen ilişkisel pazarlama kavramı üzerinde durulmuştur. İlişkisel pazarlama yöntemlerinin ilişki kalitesi üzerindeki etkisi incelenmiştir. Ayrıca İlişki kalitesi değişkenlerinden olan sadakat üzerine diğer ilişki kalitesi değişkenlerinin etkisi ölçülmüştür. Çalışmada yapısal eşitlik modeli kullanılmıştır. Yapısal eşitlik modeli karmaşık bir araştırma probleminin tek bir süreçte kapsamlı bir şekilde incelenmesini sağlayan bir modeldir. Ölçüm hatalarının hesaplanması nedeniyle yeni model oluşturulması ve var olan modelin test edilmesi için etkin olarak kullanılan model değişkenler arasındaki doğrudan etkilerin yanı sıra dolaylı etkileri de incelemektedir (Dursun ve Kocagöz, 2010: 2).

\section{BULGULAR}

Örneklem grubunun yapısı incelendiğinde cinsiyete ve medeni duruma göre müşteri sayılarının birbirine yakın seviyede olduğu görülmüştür. Yaş faktörü dikkate alındığında örneklem grubunun yarıdan fazlasının 20-29 yaş aralığında olduğu görülmüştür. Ayrıca eğitim durumuna bakıldığında örneklem grubunun yaklaşık \%70'inin en az önlisans mezunu olduğu görülmüştür (Bakınız Tablo 1). Yine Tablo 1 incelendiğinde örneklem grubunun yaklaşık \%30'unun öğrencilerden, yaklaşık $\% 16$ 'sının memurlardan, \%13'ünün öğretmenlerden, \%12'sinin akademisyenlerden, $\% 42$ 'sinin ise diğer meslek gruplarından oluştuğu görülmektedir. Aylık gelir düzeyi incelendiğinde, örneklem grubunun yaklaşı \%42'si 1000 TL'den az gelire sahip olduğu \%58'lik kısmı ise 1000 TL'den fazla gelire sahip olduğu görülmüştür. GSM Operatörü için aylık harcamalar dikkate alındığında örneklem grubunun yaklaşık 
\%72' sinin GSM operatörü için aylık 50 TL'den az harcama yaptığı, \%28'inin ise aylık 50 TL'den fazla harcama yaptığı belirlenmiştir.

Tablo 1. Demografik Özellikler

\begin{tabular}{|c|c|c|}
\hline & FREKANS & $(\%)$ \\
\hline \multicolumn{3}{|l|}{ CINSSIYET } \\
\hline Erkek & 388 & 57.7 \\
\hline Kadın & 285 & 42.3 \\
\hline \multicolumn{3}{|l|}{ MEDENİ DURUM } \\
\hline Evli & 359 & 53.3 \\
\hline Bekar & 299 & 44.4 \\
\hline Boşanmış & 15 & 2.2 \\
\hline \multicolumn{3}{|l|}{ YAŞ } \\
\hline 20'den küçük & 31 & 4.6 \\
\hline $20-29$ & 349 & 51.9 \\
\hline $30-39$ & 154 & 22.9 \\
\hline $40-49$ & 70 & 10.4 \\
\hline 49'dan Büyük & 63 & 9.4 \\
\hline Cevaplamayan & 6 & 0.9 \\
\hline \multicolumn{3}{|l|}{ EĞİTIM DURUMU } \\
\hline Okur-yazar & 5 & 0.8 \\
\hline İlköğretim & 71 & 10.5 \\
\hline Lise & 125 & 18.6 \\
\hline Önlisans & 67 & 10 \\
\hline Lisans & 283 & 42.1 \\
\hline Lisansüstü & 115 & 17.1 \\
\hline Cevaplamayan & 7 & 1 \\
\hline \multicolumn{3}{|l|}{ MESLEK } \\
\hline Serbest Meslek & 33 & 4.9 \\
\hline Öğrenci & 199 & 29.6 \\
\hline Memur & 105 & 15.6 \\
\hline Öğretmen & 87 & 12.9 \\
\hline İşçi & 46 & 6.8 \\
\hline Ev Hanımı & 30 & 4.5 \\
\hline Çiftçi & 30 & 4.5 \\
\hline Emekli & 32 & 4.8 \\
\hline Esnaf & 34 & 5.1 \\
\hline Akademisyen & 77 & 11.4 \\
\hline \multicolumn{3}{|l|}{ AYLIK GELİR } \\
\hline 1000 TL'den az & 280 & 41.6 \\
\hline 1001-2000 TL & 118 & 17.5 \\
\hline 2001- $3000 \mathrm{TL}$ & 147 & 21.8 \\
\hline 3001- $4000 \mathrm{TL}$ & 43 & 6.4 \\
\hline 4001- $5000 \mathrm{TL}$ & 59 & 8.8 \\
\hline 5000 TL'den fazla & 25 & 3.7 \\
\hline Cevaplamayan & 1 & 0.1 \\
\hline
\end{tabular}


Kullanılan GSM operatörü dikkate alındığında; tüm örneklem grubunun yaklaşık \%36'sının Turkcell Operatörünü kullandığı, \%34.9'unun Vodafone Operatörünü kullandığ1, \%28.7'sinin Avea Operatörünü kullandığ1, \%0.4'ünün ise diğer GSM operatörlerini kullandığı belirlenmiştir. Ayrıca tüm örneklem grubunun \%16'sının GSM Operatörünü 1 yıldan az süredir kullandığı, \%19.3'ünün 1-2 yıldır kullandığı, \%18.9'unun 3-4 yıldır kullandığı, \%12.3'ünün 5-6 yıldır kullandığı, \%8.8'inin 7-8 yıldır kullandığı, \%24.1'inin ise operatörünü 8 yıldan fazla süredir kullandığı görülmüştür. Yanı sıra tüm örneklem grubunun yaklaşık 3/5'inin faturalı hat sahibi olduğu, kalan 2/5'inin ise faturasız hat sahibi olduğu belirlenmiştir. Operatör değiştirme sayıları dikkate alındığında; örneklem grubunun yaklaşık \%70'lik kısmının en az bir kez operatörünü değiştirdiği görülmüştür. Kullanılan GSM operatörüne ilişkin veriler Tablo 2' de gösterilmiştir.

Tablo 2. Kullanılan GSM Operatörüne İlişkin Veriler

\begin{tabular}{lcc}
\hline & Frekans & $\mathbf{( \% )}$ \\
\hline Kullandığınız Gsm Operatörü & & \\
\hline Turkcell & 242 & 36 \\
Vodafone & 235 & 34.9 \\
Avea & 193 & 28.7 \\
Diğer & 3 & 0.4 \\
\hline Operatörü Kullanma Süresi & & \\
\hline 1 Yıldan az & 108 & 16 \\
1-2 Yıl & 130 & 19.3 \\
3-4 Yıl & 127 & 18.9 \\
5-6 Yıl & 83 & 12.3 \\
7-8 Yıl & 59 & 8.8 \\
8 Yıldan fazla & 162 & 24.1 \\
Cevaplamayan & 4 & 0.6 \\
\hline Kullanılan Hat Türü & & \\
\hline Faturalı & 395 & 58.3 \\
Faturasız & 271 & 40.7 \\
Cevaplamayan & 7 & 1 \\
\hline Operatör Değiştirme Sayısı & & \\
\hline Hiç & 209 & 31.1 \\
1 kez & 162 & 24.1 \\
2 kez & 169 & 25.1 \\
3 kez & 91 & 13.5 \\
Cevaplamayan & 39 & 5.8 \\
\hline
\end{tabular}

Ölçeğin geçerliliği göz önüne alındığında, her bir ölçeğin geçerlilik çalışması için doğrulayıcı faktör analizi yapılmış ve ölçeğin geçerli olduğu sonucuna varılmıştır. Doğrulayıcı faktör analizi sonucunda V1, V7 ve V11 soruları çıkarılmış ve değerlendirmeye alınmamıştır. Diğer sorular ise aynı şekilde değerlendirmeye tabi tutulmuştur. 
Yol Analizi (Path Analizi): Path analizi çoklu regresyon modellerinin mantıksal ifadesi ve bir kuramsal ilişkiler testi olarak tanımlanabilir. Bu analiz değişkenlerin birbiri üzerindeki doğrudan ve dolaylı etkilerini ölçülebilmektedir. Araştırmalar path analizi yönteminin nedensel analizlerin yapılmasında regresyon analizinden daha üstün olduğunu göstermektedir. Bu modelde tüm bağımsız değişken kombinasyonlarını tek şekilde görüp yorumlamak mümkündür. Yol analizinde dış değişkenlerin iç değişkenler üzerinde etkisinin yönü belirlenir ve bu doğrultuda analiz yapılır (Çokluk vd, 2014: 338).

Hipotezlerin analizi aşamasında t değerlerinin 1.96'dan büyük olması hipotezin 0.05 düzeyinde anlamlı olduğunu 2.56'dan büyük olması hipotezin 0.01 düzeyinde anlamlı olduğunu göstermektedir (Şimşek, 2007 akt. Çapık, 2014: 203).

Aşağıda yapılan araştırmada yol analizi için kurgulanan t değerleri ve ifade ettiği anlamlar verilmiştir.

V1: Uzun bir süre daha hizmet aldığım operatörü kullanmaya devam edeceğim.

V2: Farklı bir operatör düşük fiyatlı da olsa operatörümü kullanmaya devam edeceğim.

V3: Diğer insanlara kullandığım operatör hakkında olumlu şeyler söylemek isterim.

V4: Yakınlarım ve arkadaşlarımı kullandığım operatörü kullanmaları için teşvik ederim.

V5: Kullandığım operatörün bana en iyi hizmeti sunduğunu düşünüyorum.

V6: Yeni bir cep telefonu hattı almayı düşünsem hiç kuşkusuz yine ilk tercihim bu hat olurdu.

değerleri müşteri sadakatini ifade etmekte,

V7: Kullandığım operatör müşteri çıkarları konusunda oldukça duyarlı olduğundan güvenilirdir.

V8: Operatörüm güvenilir bir fatura sistemine sahiptir.

V9: Operatörüm güvenilir bir itibara sahiptir.

V10: Operatörüm tarafından sağlanan müşteri hizmetleri süreci güvenilirdir.

değerleri müşteri güvenini ifade etmekte,

V11: Kullandığım operatör tarafından sunulan tüm hizmet kalitesinden memnunum.

V12: Kullandığım operatörün bir GSM hattı olarak yeterliliğinden memnunum.

V13: Kullandığım operatörün ön cephe çalışanlarından memnunum. 
V14: Hattımla ilgili bir problem yaşarsam rahatça müşteri hizmetleriyle iletişim kurabilirim.

değerleri müşteri memnuniyetini ifade etmekte,

V15: Kullandığım operatörün ürün ve hizmet fiyatlama politikası caziptir.

V16: Ödediğim ücrete karşılık operatör tarafından sunulan telefon etme süreleri makuldur.

V17: Kullandığım operatör ihtiyacım olan çeşitli hizmetler (internet,sms, arama v.b) için esnek fiyat politikası uygular.

V18: Aldığım hizmetler için fiyat önemli derecede yükselmedikçe kullandığım operatörde kalmaya devam edeceğim.

değerleri müşteri fiyat algısını ifade etmekte,

V19: Kullandığım operatör müşteri taleplerini karşılamak için güncel yöntemler takip eder.

V20: Kullandığım operatör ön cephe (müşteriyi ilk karşılayan) çalışanları daima bana yardım etmek için isteklidirler.

V21: Kullandığım operatör kaliteli hizmet sağlar.

V22: Kullandığım operatör müşteri ihtiyaçlarını karşılamak için kişisel hizmet sunar.

V23: Kullandığım operatör yeni hizmetleri ile ilgili bilgilendirme yapar.

değerleri hizmet kalitesini ifade etmekte,

V24: Operatörüm kendi müşterilerine olumlu bir marka imajı vermektedir.

V25: Operatörümün sosyal sorumlulukları konusunda üzerine düşeni yaptığına inaniyorum.

V26: Operatörümün saygınlığının yüksek olduğunu düşünüyorum.

değerleri marka imajını ifade etmekte,

V27: Hizmet aldığım operatör firma, güçlü ve sağlam bir kuruluştur.

V28: Hizmet aldığım operatör firma, yenilikçi ve öncü bir firmadır.

V29: Hizmet aldığım operatör firma ülkemiz için yararlı şeyler yapmaktadır.

V30: Hizmet aldığım operatör firma sektöründe liderdir.

V31: Hizmet aldığım operatör firmanın kamuoyunda iyi bir imajı vardır.

değerleri ise şirket imajını ifade etmektedir. 


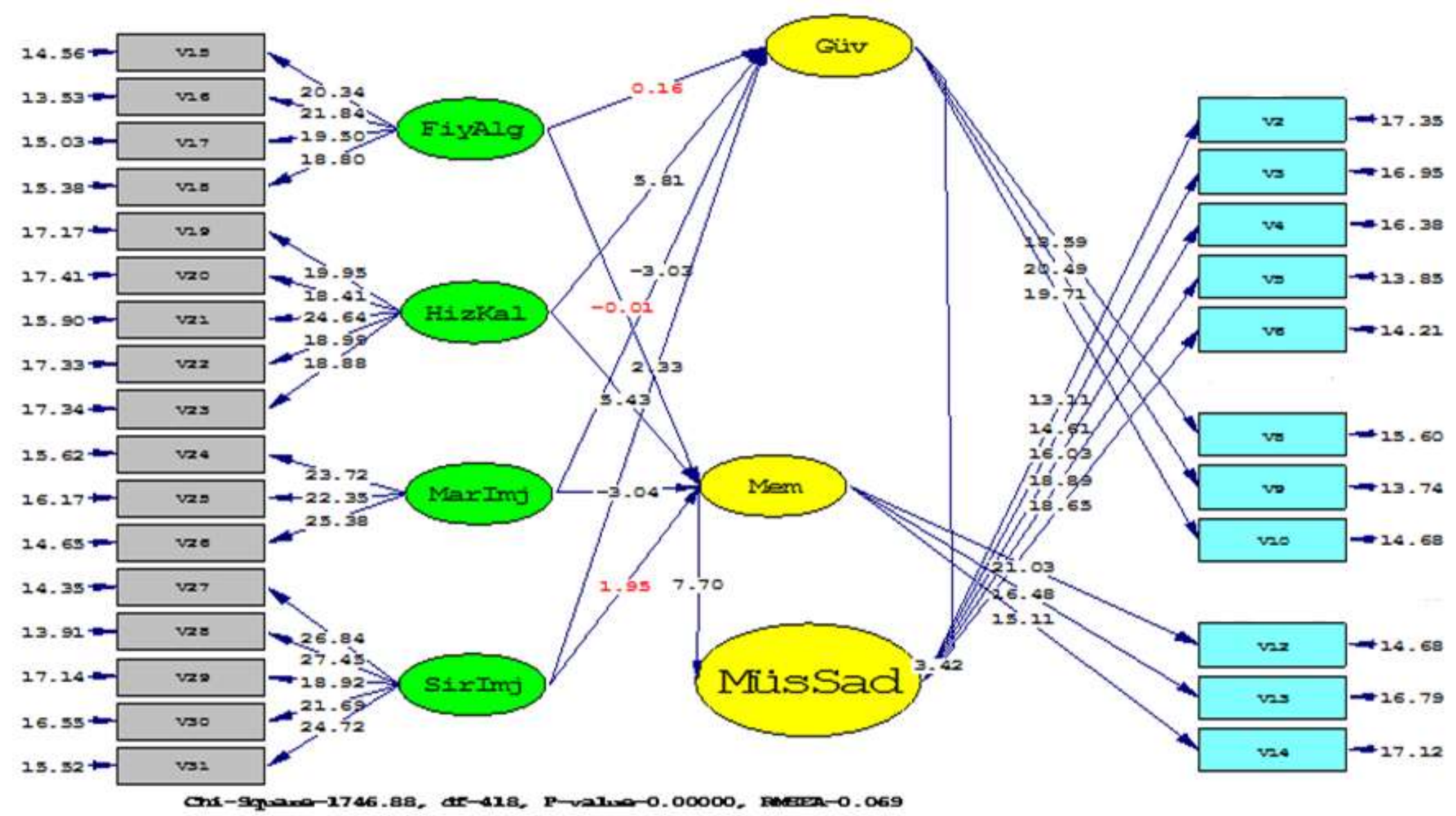

Şekil 2. Yol Analizi İçin Kurgulanan T Değerleri 
Tablo 3. Oluşturulan Modelin Uyum İndeksleri

\begin{tabular}{|l|l|l|l|}
\hline $\begin{array}{l}\text { Uyumluluk } \\
\text { İndeksi }\end{array}$ & $\begin{array}{l}\text { Modifikasyon } \\
\text { Öncesi Değerler }\end{array}$ & $\begin{array}{l}\text { Modifikasyon } \\
\text { Sonrası Değerler }\end{array}$ & $\begin{array}{l}\text { Kabul Edilebilir } \\
\text { Uyum }\end{array}$ \\
\hline Ki-Kare & 1746.88 & 1584.15 & \\
\hline $\begin{array}{l}\text { Serbestlik } \\
\text { Derecesi }\end{array}$ & 418 & 416 & $1-5$ \\
\hline $\begin{array}{l}\text { Ki-Kare/ } \\
\text { serbestlik } \\
\text { derecesi }\end{array}$ & 4.179 & 3.808 & RMSEA $\leq 0.08$ \\
\hline RMSEA & 0.069 & 0,065 & NFI $\geq 0.90$ \\
\hline NFI & 0.97 & 0,97 & NNFI $\geq 0.90$ \\
\hline NNFI & 0.98 & 0,98 & CFI $\geq 0.90$ \\
\hline CFI & 0.98 & 0.98 & RMR $\leq 0.08$ \\
\hline RMR & 0.65 & 0.058 & SRMR $\leq 0.08$ \\
\hline SRMR & 0.049 & 0,044 & \\
\hline
\end{tabular}

Uyum indeksleri incelendiğinde modifikasyon öncesi 4.179 olan Ki-kare/ Serbestlik derecesini 3.00'a yaklaştırılması amacıyla modifikasyon yapılmış ve sonuçta değer 3.808' e düşerek daha iyi bir uyum elde edilmiştir. Kök ortalama kare yaklaşım hatasinın (Root Mean Squeare error of approximation-RMSEA) normal derecede (0.065) uyumluluğa sahip olduğu, normlanmış uyum indeksinin (Normed Fit IndexNFI) mükemmel derecede(0.97) uyuma sahip olduğu, normlanmamış uyum indeksinin (Non-normed fit index-NNFI) mükemmel derecede (0.98) uyuma sahip olduğu, karşılaştırmalı uyum indeksinin (Comparative Fit Index-CFI) mükemmel bir uyuma (0.98) sahip olduğu, ortalama hataların kare kökünün (Root Mean Square ResidualRMR) normal derecede (0.065) uyuma sahip olduğu, standardize edilmiş ortalama hataların kare kökünün (Standardized Root Mean Square Residual-SRMR) mükemmel derecede (0.049) uyumluluğa sahip olduğu görülmüştür.

H1: Hizmet kalitesi müşteri memnuniyetini etkiler.

Araştırma verileri incelendiğinde hizmet kalitesinin müşteri memnuniyeti üzerine 0.01 anlamlılık düzeyinde pozitif bir etkisinin olduğu sonucuna varılmıştır.

H2: Hizmet kalitesi müşteri güvenini etkiler.

Araştırma verileri incelendiğinde hizmet kalitesinin müşteri güvenini 0.01 anlamlılık düzeyinde pozitif yönde etkilediği sonucuna varılmıştır.

H3: Fiyat alg1sı müşteri memnuniyetini etkiler.

Araştırma verileri incelendiğinde fiyat algısının müşteri memnuniyetini etkilemediği sonucuna varılmıştır.

H4: Fiyat algısı müşteri güvenini etkiler. 
Araştırma verileri incelendiğinde fiyat algısının müşteri güvenine etkisinin olmadığını görülmüştür.

H5: Marka imajı müşteri memnuniyetini etkiler.

Araştırma verileri incelendiğinde marka imajının müşteri memnuniyeti üzerine 0.01 anlamlılık düzeyinde negatif yönde bir etkiye sahip olduğu sonucuna varılmıştır.

H6: Marka imajı müşteri güvenini etkiler.

Araştırma verileri incelendiğinde marka imajının müşteri güveni üzerine 0.01 anlamlılık düzeyinde negatif yönde bir etkiye sahip olduğu sonucuna varılmıştır.

H7: Şirket imajı müşteri memnuniyetini etkiler.

Araştırma verileri incelendiğinde şirket imajının müşteri memnuniyeti sınır (1.95) seviyesinde etkilediği görülmüş ve 0.05 anlamlılık düzeyine yakın olduğu görülmesine rağmen hipotez kabul edilmemiştir.

H8: Şirket imajı müşteri güvenini etkiler.

Araştırma verileri incelendiğinde şirket imajının müşteri güveni üzerinde 0.05 anlamlılık düzeyinde pozitif bir etkiye sahip olduğu sonucuna varılmıştır.

H9: Müşteri güveni müşteri sadakatini etkiler.

Araştırma verileri incelendiğinde müşteri güveninin müşteri sadakati üzerine 0.01 anlamlılık düzeyinde pozitif etkiye sahip olduğu sonucuna varılmıştır.

H10: Müşteri memnuniyeti müşteri sadakatini etkiler.

Araştırma verileri incelendiğinde müşteri memnuniyetinin müşteri sadakatine 0.01 anlamlılık düzeyinde pozitif etkiye sahip olduğu sonucuna varılmıştır.

\section{SONUÇ}

Araştırmada müşteri sadakati ve ilişki kalitesi üzerine ilişkisel pazarlama yöntemlerinin etkisi incelenmiştir. Diğer bir ifadeyle müşteri memnuniyeti ve müşteri güveni gibi bağımlı değişkenler üzerine hizmet kalitesi, fiyat algısı, şirket imajı ve marka imajı gibi bağımsız değişkenlerin etkisi incelenmiştir. Ayrıca müşteri memnuniyeti ve müşteri güveninin müşteri sadakati üzerine etkisi incelenmiştir.

Fiyat algısının müşteri güveni ve memnuniyetini etkilemediği sonucuna varılmıştır. Türkiye'de bulunan GSM operatörlerine ait bazı tarife verileri aşağıdaki gibi gösterilebilir.

- Turkcell interneti bol $1000 \mathrm{dk}$ 4GB internet $1000 \mathrm{sms}$ tarifesinin fiyatının $59 \mathrm{TL}$ olduğu (http://www.turkcell.com.tr)

- Vodafone mavi akıllı küp tarifesinin(750 dk,1000 sms, 2GB internet) fiyatının 49 TL olduğu(http://www.vodafone.com.tr)

- Avea bol kepçe tarifesinin(600dk,3GB internet, sınırsız sms) fiyatının $45 \mathrm{TL}$ olduğu (http://www.avea.com.tr) 
görülmüştür. Bu verilerden hareketle yakın özelliklere sahip tarifelerin birbirine yakın fiyatlara sahip olduğu görülmektedir. Bu durum fiyat algısının müşteri memnuniyeti ve müşteri güveni üzerine etkisinin olmamasına neden olmaktadır.

Araştırma verileri dikkate alındığında marka imajının müşteri memnuniyetini ve müşteri güvenini ters yönde etkilediği görülmüştür. Bir genelleme yapılmamakla birlikte Kars ilinde GSM operatörü müşterilerinin marka imajı yüksek olan GSM operatöründen memnun olmadıkları ve bu operatörlere güvenmedikleri sonucuna varılmıştır. Yapılan araştırmada GSM operatörü müşterileri en yüksek marka imajına sahip GSM operatörünün Turkcell olduğunu belirtmişlerdir. Ancak Türkiye'de GSM sektöründe mobil operatörlerin pazar payları incelendiğinde Turkcell şirketinin pazar payının 2012'den günümüze bir düşüş gösterdiği görülmektedir. Ayrıca GSM operatörlerine geçiş sayıları incelendiğinde; GSM operatörü müşterileri tarafından en fazla diğer operatörlere geçiş yapılan GSM operatörünün Turkcell olduğu görülmektedir. Bu verilerden hareketle Türkiye'de Turkcell operatörünün son yıllarda kullanımında bir düşüş meydana geldiği görülmektedir (teknolojigundem.com). Bu durum ise hipotezi destekleyen bir durum olarak karşımıza çıkmaktadır. Yani Kars ilinde marka imajı en yüksek GSM operatörü Turkcell olarak bilinmektedir. Ancak marka imajının yüksek olması müşteri memnuniyeti ve müşteri güvenini olumsuz etkilemektedir. Bu durumun nedeni memnuniyet ve güveni etkileyen diğer faktörlerin etkisinin marka imajının etkisine nazaran daha yüksek olmasıdır denebilir. Bunun dışında şirket imajının müşteri memnuniyetini ve müşteri güvenini olumlu yönde etkilediği sonucuna varılmıştır. Ayrıca araştırma verileri Kars ilindeki GSM operatörü müşterilerinin memnuniyeti ve güveni açısından şirket imajının önemli bir etkiye sahip olduğunu göstermiştir. Müşteri güveninin ve müşteri memnuniyetinin müşteri sadakati üzerine etkisi incelenmiş ve müşteri memnuniyetinin müşteri sadakatini en çok etkileyen ilişki kalitesi yöntemi olduğu sonucuna varılmıştır. Yanısıra müşteri güveni de müşteri sadakatini olumlu yönde etkilemektedir.

Araştırma verilerine göre; Kars ilindeki GSM operatörü müşterilerinin memnuniyetlerini etkileyen en önemli faktör yüksek hizmet kalitesidir. Müşteriler diğer ilişkisel pazarlama yöntemlerinden ziyade yüksek hizmet kalitesi sunan GSM operatörlerinden daha fazla memnun olmaktadır. Kars ilinde GSM sektöründe müşteri güvenini etkileyen en önemli ilişkisel pazarlama yönteminin de yine hizmet kalitesi olduğu belirlenmiştir.

Raza ve Rehman (2012) tarafından yapılan çalışmada müşteri sadakati ile ilgili; Müşteri Sadakati= 0.816(Müşteri Memnuniyeti) + 0.069(Müşteri Güveni) şeklinde yorumlanmıştır. Kars ilinde yapılan çalışmada ise bu sonuca paralel olarak müşteri sadakatine; Müşteri Sadakati= 0.770 (Müşteri Memnuniyeti) + 0.342(Müşteri Güveni) şeklinde fonksiyonel olarak yorumlanabilir.

Yapılan araştırmada bu değişkenlerin birbirleri arasındaki ilişki incelenmemiş olup gelecek çalışmalarda bağımsız değişkenlerin(hizmet kalitesi, fiyat algısı, marka imajı ve şirket imajı) birbirleri arasındaki ilişki ve bağımlı değişkenlerin (müşteri memnuniyeti, müşteri güveni ve müşteri sadakati) birbirleri arasındaki ilişkileri incelenebilir. 


\section{KAYNAKÇA}

AVEA,http://www.avea.com.tr/web/KonusMesajlas/Tarifeler/Faturali (27.05.2015)

Bayuk, M.N., Küçük, F. (2007). "Müşteri Tatmini ve Müşteri Sadakati İlişkisi”, Marmara Üniversitesi İktisadi ve İdari Bilimler Fakültesi Dergisi, Cilt: 22 sayı: 1.

Bowen, J.T., Chen, S. (2001). “The Relationship Costumer Loyalty and Costumer Satisfaction” , İnternational Journal of Contemporary Hospitaly Management, Vol: 13, no: 5.

Burcuoğlu, M. (2011). "Müşteri Memnuniyeti ve Sadakatini Arttırmada Müşteri Şikayetleri Yönetiminin Etkinliği: Bir Örnek Olay İncelenmesi." Yayımlanmamış Yüksek Lisans Tezi, Karamanoğlu Mehmet Bey Üniversitesi Sosyal Bilimler Enstitüsü İşletme Anabilim Dalı, Karaman.

Chiu, H., Hsieh, Y., Li, Y., Lee, M. (2005). “Relationship Marketing and Consumer Switching Behavior", Journal of Business Resarch, vol: 58, no: 12, pp.1681-1689.

Çokluk, Ö., Şekercioğlu, G. ve Büyüköztürk, Ş. (2014). Sosyal Bilimler için Çok Değişkenli İstatistik SPSS ve LISREL Uygulamaları, Pagem Akademi Yayınları, Ankara.

Dursun, Y., Kocagöz, E. (2010). "Yapısal Eşitlik Modeli ve Regresyon: Karşılaştırmalı Bir Analiz." Erciyes Üniversitesi İktisadi ve İdari Bilimler Fakültesi Dergisi, Sayı: 35, ss.117.

Ekici, K., Yüce, A. (2007). “CRM Müşteri İlişkileri Yönetimi” , Savaş Yayınevi, Ankara.

Erdoğan, Z., Develioğlu, K., Gönüllüoğlu, S., Özkaya, H. (2006). “Kurumsal İmajın Şirketin Farklı Paydaşları Tarafından Algılanışı Üzerine Bir Araştırma" , Dumlupınar Üniversitesi Sosyal Bilimler Dergisi, Sayı: 15, ss.55-76.

Filiz, Z., Yılmaz, V., Yağızer, C. (2010). “Belediyelerde Hizmet Kalitesinin Serqual Analizi İle Ölçümü: Eskişehir Belediyelerinde Bir Uygulama" , Anadolu Üniversitesi Sosyal Bilimler Dergisi, Cilt: 10, Sayı: 3, ss.59-76.

Gerson, R. F. (1997). Müşteri Tatmininde Süreklilik , (Savaşer T. Çev.), Rota Yayınları, İstanbul.

Hacıefendi, Ş., Koç, Ü. (2009). “Hizmet Kalitesi Algılamalarının Müşteri Bağlılığına Etkisi ve Fast-Food Sektöründe Bir Araştırma", Kocaeli Üniversitesi Sosyal Bilimler Enstitüsü Dergisi, Sayı: 18, ss.146-167.

Hacıefendioğlu, Ş., Çolular, N. (2008). "İlişkisel Pazarlamada Güven Unsuru ve Otel İşletmelerinde Uygulama" Kocaeli Üniversitesi Sosyal Bilimler Enstitüsü Dergisi, Sayı: 16 , ss.107-126.

Hashem, T. N. (2012). The Impact of Costumer Relationship Marketing on Costumers' Satisfaction for the Banking Industry in Jordan, Internitional Journal of Management Cases, Amman.

Kökalan, Ö. (2004). "Satış Departmanında Çalışanların Şirket İmajına Katkılarının İncelenmesi” Yayımlanmamış Yüksek Lisans Tezi, Yıldız Teknik Üniversitesi Sosyal Bilimler Enstitüsü İşletme Anabilim Dalı, İstanbul.

Özdağoğlu, A., Özdağoğlu, G., Öz, E. (2008). “Müşteri Sadakatinin Sağlanmasında Müşteri İlişkileri Yönetiminin Önemi" , Atatürk Üniversitesi İktisadi ve İdari Bilimler Dergisi." Cilt: 22, Sayı: 1.

Pappers, D. "Bire Bir Pazarlama" , DataSel Yayınları, İstanbul.

Peltekoğlu, F.B. (2007). Halkla İlişkiler Nedir? , Beta Yayınları, İstanbul. 
Rahman, S., Erdem, R., Devebakan, N. (2007). "Hizmet Kalitesinin Serqual Ölçeği ile Değerlendirilmesi: Elazı̆̆'daki Hastaneler Üzerinde Bir Çalışma" , Dokuz Eylül Üniversitesi Sosyal Bilimler Enstitüsü Dergisi, Cilt: 9, Sayı: 3, ss.37-55.

Raza, A. ve Rehman, Z. (2012). Impact of Relationship Marketing Tactics On Relationship Quality And Costumer Loyalty: A case study of telecom sector of Pakistan, African Journal of Business Management Vol. 6(14), ss.5085-5092.

TDK(Türk Dil Kurumu) http://www.tdk.gov.tr/index.php?option=com_gts\&arama=gts\&guid=TDK.GTS.54c8e39 b8579f7.85102703 ( 28.01.2015).

Teknolojigündem http://www.teknolojigundem.com/telekom-haberleri/btk-acikladi-mobilabone-sayisi-70-milyonu-gecti-598290.htm\# (11.05.2015).

TUIK (Türkiye İstatistik Kurumu) http://www.tuik.gov.tr/PreHaberBultenleri.do?id=18616 , (11.05.2015).

Turkcell http://www.turkcell.com.tr/kampanyalar/yeni-turkcell-musterisi/interneti-bol-1000dk4gb-1000sms-paketi-yeni-musteri-firsat-kampanyasi?place=banner-3 , (27.05.2015).

Vodafone http://www.vodafone.com.tr/Tarifeler/AkilKupuTarifeler.php\#mevcutvodafonelular, (27.05.2015).

Yalçınkaya, G. (2006). “Ülke İmajı ve Ülke İmajının Müşteri Tercihleri Üzerine Etkisi: Türkiye Değerlendirmesi" , Yayımlanmamış Yüksek Lisans Tezi, Dokuz Eylül Üniversitesi Sosyal Bilimler Enstitüsü İşletme Anabilim Dalı, İzmir.

Yurdakul, M. ( 2007 ). “ İlişkisel Pazarlama Anlayışında Müşteri Sadakati Olgusunun Ayrıntılı Bir Şekilde Analizi" , Dumlupınar Üniversitesi Sosyal Bilimler Enstitüsü Dergisi, Sayı: 17 , ss. 268-287. 